\title{
NATIONAL CAPACITY BUILDING STRATEGY IN LEARNING: AN ASSESSMENT OF ARREARAGE IN NIGERIAN UNIVERSITIES
}

UDEME AKANIYENE UMO AND JACOB EFFIONG ESIN

(Received 20, March 2015; Revision Accepted 10, April 2015)

\begin{abstract}
The primary role of a library all over the world is to meet the information needs of its service population in a timely and economic manner by acquiring processing and dissemination both print and non print information resources produced both inside and outside the organization. This objective may be farfetched if resources are acquired but remained in the processing division of libraries for quite a reasonable length of time before processing is initiated. Two academic libraries in Nigeria; the University of Uyo and University of Calabar libraries were accessed on how promptly their resources are acquired and processed, so as to distribute them to users for capacity building and sustainable development. Result of this research clearly shows that though these two libraries regularly acquired rich information resources, but remained in the processing division for more than 10 months before processing starts. It is an indication that, they are into arrearage and cannot contribute to sustainable development and poverty alleviation of the users. Questionnaire and visit to the libraries were the instrument used by the researcher, causes of arrearage were identified as inadequate professional staff in the cataloguing and classification division and low working experience of staff in this division among others. It is recommended that the backlog i.e. books yet to be catalogued should be made accessible to user by filing their slip at the catalogue.
\end{abstract}

KEYWORDS: Learning, Capacity building, Assessment, Arrearage, University, Nigeria

\section{INTRODUCTION:}

Arrearage could be defined as those resources in the cataloguing and classification divisions of the Library which for various reasons have not yet been catalogued or processed. It is a situation whereby libraries and information centres acquired information resources but allowed these materials to remain for more than 10 months before processing. This paper attempts to examine the situation in the University of Calabar and the University of Uyo libraries, for positive national capacity building strategy in learning and sustainable development in Nigeria.

Byron (2000) opined, that there are two types of arrearage, namely booked delayed unduly or halted in their progress through series of processing operations right from receipt to completion of cataloguing for any reason whatever and books deliberately segregated for preferred treatment.

Charles (2001) stated that a library that keeps little or more quantity of books in the classification division for more than 10 months before complete processing has the problem of arrearage.

There is not much literature about the subject of library arrearages especially when it relates to Nigeria. This paucity of literature was observed by Victor (2001) and Mensah (2003) respectively when they had a survey on the

Udeme Akaniyene Umo, Department of Educational Foundations, Guidance and Counseling, University of Calabar, Calabar, Cross River State Nigeria.

Jacob Effiong Esin, Department of Library and Information Science, University of Calabar, Calabar, Cross River State Niaeria. 
subject in African and Canadian university libraries.

Rogers and Adeya (2004), observes that there is no justification for an acquisition of librarian and the cataloguers to allow library books remain in their divisions for more than one year.

They define arrearage as books which remained in the acquisition and cataloguing division for more than 6 months for whatever reasons. Dale (2009), has stated that inadequate working tools and personnel in the acquisition and cataloguing division may contribute to the problem of arrearage According to him, arrearage in most cases may not be deliberately caused by these librarians.

Lucan (2000) stated that staff experience in the technical unit of the library may contribute to quick processing of Books or delay in processing.

\section{Objective}

The purposes of this study are:

a) To determine the extent of existence of arrearage in the acquisition and the processing division of the surveyed university libraries.

b) To investigate reasons for occurrence of arrearage

c) To determine the subject area in which arrearage occur in survey libraries

d) To determine whether arrearage books are in the catalogue.

e) To investigate whether there is adequate conservation and preservation of arrearage books.

\section{RESEARCH QUESTIONS}

Based on the objectives of the study the following research questions were proposed to guide the study.

1. Does arrearage exist in the acquisition and processing division of these libraries?

2. What are the reasons for existence or non existence of arrearage?

3. What is the subject in which arrearage occurs?

4. What preservation and conservation method is employed on these arrearage books?

\section{Data collection method}

questionnaire.

A total of 200 questionnaires were administered to staff in the cataloguing and classification division of the surveyed university libraries. 169 questionnaires were returned indicating $84.5 \%$. The University of Calabar library has a total of ninety eight (98) staff; professional 39; paraprofessional 47; non professional 12.

The University of Uyo library has a total of seventy one (71) staff, professional 19 paraprofessional 31 non professional 2. The paraprofessionals are those with Diploma in Library and Information Science. (DLS), professional are those with BLS. MLS, PhD in library and information science while nonprofessional are those without certificate in library science.

The sampling method used to select respondents, was stratified randomly sampling (Osuala 2000). Face to face survey was adopted due to its high response rate. However, some 4questions required direct and factual answers since there is, library statistics or the acquisition and processing capacity during a certain period of time. 


\section{RESULTS AND DISCUSSION}

Table 1: Working experience of respondents

\begin{tabular}{|l|l|l|l|}
\hline S/N & Year & Response & Percentage \% \\
\hline 1 & Below 10 years & 121 & 72 \\
\hline 2 & Between 11 and 15 years & 38 & 22 \\
\hline 3 & Between 16 and 20 years & 08 & 08 \\
\hline 4 & Above & 02 & 01 \\
\hline
\end{tabular}

\section{DISCUSSION}

Table 1: indicates that the largest groups of respondents had below 10 years of working experience i.e. 121 (72\%) followed by $38\left(22^{\circ} ! 0\right)$ respondents having between 11 and 15 years.

Staff who spent many years on service could gain more experience and thereby processed books rapidly than those that spent less number of years. This shows that delay in book processing is likely to occur thereby leading to arrearage

This is in support of Lucas (2000) who stated that staff in this technical area must be highly experience.

Table 2: Duration of books in your division Before forwarding

\begin{tabular}{|l|l|l|l|}
\hline S/N & Duration & Response & Percentage \% \\
\hline 1 & Less than 6 months & 32 & 19 \\
\hline 2 & $6-12$ months & 102 & 60 \\
\hline 3 & $1-2$ months & 35 & 21 \\
\hline 4 & Above 2 months & Nill & - \\
\hline & Total & $\mathbf{1 6 9}$ & $\mathbf{1 0 0}$ \\
\hline
\end{tabular}

On the duration of books in the unit, table 2, indicates highest respondents of 102 (60\%) showing that book remained in these divisions between 6-12 months before final processing. 32
$(19 \%)$ respondents indicated that it remains for less than 6 months. Charles (2000) stated that libraries that keep books for more than 10 months before processing has arrearage.

Table 3: point at which there is arrearage

\begin{tabular}{|l|l|l|l|}
\hline S/N & Different points & Response & Percentage \% \\
\hline 1 & Typing point & 38 & 22 \\
\hline 2 & Cataloguing/classification & 98 & 58 \\
\hline 3 & Ticket production point & 19 & 12 \\
\hline 4 & Accessing point & 09 & 05 \\
\hline & Book labeling point & 05 & 03 \\
\hline & Total & $\mathbf{1 6 9}$ & $\mathbf{1 0 0}$ \\
\hline
\end{tabular}

According to table $3,98(58 \%)$ of the respondent said that, arrearage occurs during the cataloguing and classification of books while
$38(22 \%)$ is said to occur at the point of typing books. $19(12 \%)$ of the respondents said it occurs at the point of ticket production. 
Table 4: Reasons for arrearages

\begin{tabular}{|l|l|l|l|}
\hline S/N & Different points & Response & Percentage \% \\
\hline 1 & Poor working environment & 06 & 4.0 \\
\hline 2 & Poor staff motivation & 05 & 3.0 \\
\hline 3 & Poor remuneration & 04 & 2.0 \\
\hline 4 & Inadequate professional staff & 127 & 75.0 \\
\hline 5 & Insufficient tools & 27 & 16.0 \\
\hline & Total & $\mathbf{1 6 9}$ & $\mathbf{1 0 0}$ \\
\hline
\end{tabular}

Once the particular areas of delay have been identified, the next step would be to know why there are arrearages in those specific areas. Table 4 , reveals that 127 or $75 \%$ said inadequate professional staff is the major reasons. $27(16 \%)$ of the respondent said that insufficient tools was the major reason. 06(4\%) respondents said poor working environment was the major reasons. 5 or $3 \%$ respondents indicated that poor staff motivation was the major reasons while 4 or $2 \%$ of the respondents said poor remuneration was the major reason.

Table 5: Subject discipline with arrearage

\begin{tabular}{|l|l|l|l|}
\hline S/N & Disciplines & Response & Percentage \% \\
\hline 1 & Science related books & 14 & 8.2 \\
\hline 2 & Art related book & 08 & 5.0 \\
\hline 3 & Social science book & 07 & 4.1 \\
\hline 4 & Law related books & 09 & 5.3 \\
\hline 5 & Books in all discipline & 131 & 78.0 \\
\hline & Total & $\mathbf{1 6 9}$ & $\mathbf{1 0 0}$ \\
\hline
\end{tabular}

On the subject discipline in which arrearage occurs, table 5 , provide answer to that research question. Finding reveals that $131(78 \%)$ of the respondents stated that it is in all discipline. 14
$(8.2 \%)$ indicates that it is in science related books. Art books followed with 8 or $5 \%$ and social sciences with 7 or $4 \%$ responses respectively.

Table 6: Representation of arrearage in the catalogue

\begin{tabular}{|l|l|l|l|}
\hline S/N & Presentation & Response & Percentage \% \\
\hline 1 & Yes & - & - \\
\hline 2 & No & 169 & 100 \\
\hline
\end{tabular}

The catalogue is the key or index to the holding of any library which informs users of what is available in the particular library. The author wanted to know if the arrearage is in the catalogue. This was considered important because if a book can stay as long as three years in a library without users knowing them, such a book must be considered waste. Table 6 shows that arrearage are riot presented in the catalogue as indicated by all the respondents i.e. $100 \%$ of the respondent 
Table 7: Presentation of arrearage

\begin{tabular}{|l|l|l|l|}
\hline S/N & Duration & Response & Percentage \% \\
\hline 1 & In a store with open access & 06 & 4 \\
\hline 2 & In a store with close access & 21 & 12 \\
\hline 3 & In a special shelf & 14 & 8 \\
\hline 4 & Stored in processing and acquisition division & 128 & 76 \\
\hline & Total & $\mathbf{1 6 9}$ & $\mathbf{1 0 0}$ \\
\hline
\end{tabular}

Preservation of the print materials in our library is very importan 1 it is on this strength that the authors are interested in the preservation of the arrearage in the chosen academic libraries so as to sustain the physical condition of the Books. As seen in table 7, $128(76 \%)$ respondents indicated that they are preserved in the acquisition and the processing department. 21 (I2\%) of the respondents stated that they are persevered in a store with closed access. $14(8 \%)$ stated that they are kept in a special shelf. The least response $6(4 \%)$ stated that they are kept in the store with open Access.

\section{CONCLUSION AND RECOMMENDATION}

The findings of this survey on the situation of arrearage in the acquisition and the processing divisions of the two surveyed academic libraries has been quite revealing, showing that arrearage exist in these libraries as many respondents indicates that Books remained in their division between 6-12 months before final processing. This is in line with Charles (2001) who stated that libraries that keep books for more than 10 months before final processing has arrearage. It was not surprising when the cause of the arrearage were identified mainly as inadequate staff especially the professional staff, typist, cataloguers and classifiers.

There is an urgent need for human capacity building for sustainable development in the library sectors of tertiary institutions in Nigeria. Though the authorities may not have adequate funds to employ enough catalogers, the few that are available should be made comfortable so that they could work optimally and beside, they should be encouraged so that doing the job is a joy and not a burden. Both Junior and senior staff should have opportunity to attend short term courses and seminars to update themselves. The chief cataloguer should notify all cataloguers that difficult titles should be set aside to be handled during "co-operative cataloguing" to be indicated regularly

It was amazing when a responding cataloguer asked "what will the catalogue staff be doing if there is no backlog, do you want us to be redundant21' In the light of this question, one might say a little backlog with user's access is healthy but a situation in which a book is in the cataloguing section for one to six years is unhealthy. Its clearly seen that in the two academic libraries, the backlog is not represented in the users catalogue, hence no access. Some librarians may criticize this representation on the catalogue on the grounds that it wastes. Time that should have been spent on cataloguing and typing. The advantages may outweighs disadvantages if put on trial.

Better still, at the point of ordering in the acquisition sections of libraries, an extra slip may be made so that when such books arrives in the cataloguing section, the slip is withdrawn, the book is then given a number within the subject area, and the slip is filed in the public catalogue with the label undergoing processing.

Finally, it is quite easy to be busy doing nothing It is suggested that the chosen academic libraries should keep detailed record of performance so that each staff can assess himself and take correction where necessary Academic libraries should walk out ways of treating difficult titles instead of allowing them to stay indefinitely in the cataloguing division. The library should endeavour to have enough and qualified cataloguers so as to reduce backlog, and also be able to contribute to the national capacity building for sustainable development and poverty alleviation in Nigeria. 


\section{REFERENCES}

Byron, O. B., 2000. Cataloguing and Bibliography Control Problem. International Library Review (9):3.

Charles, L B., 2001. "Managing the Catalogue Department in Libraries" Journal of Information Science. (1):3.

Date, Q L., 2009. Organizing Knowledge for Coping with Problems Aslib Processing $31(1)$ :

Lucas, O. E., 2000 The Practice of Cataloguing London Heinemann.
Roger, J. E and Adeya, S. O., 2004. Organization of Knowledge in Nigeria Libraries, London Heinemann.

Osuala, J. O. 2000. Cataloguing and Classification, New York Pergamon Press.

Rashid, M. G., 2008. Book Availability and the Library User. New York. Pergamon Press.

Raymond, S. L., 2007. Cataloguing in Developing Countries Libraries Urbana, University Illinois Press.

Kent, P. N., 1994. "How to Evaluate Serial Suppliers" Library Acquisitions" Practice and Theory. 